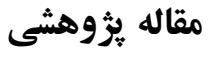 \\ مجله دانشگاه علوم يزشكى رفسنجان \\ دوره •r، دى •*

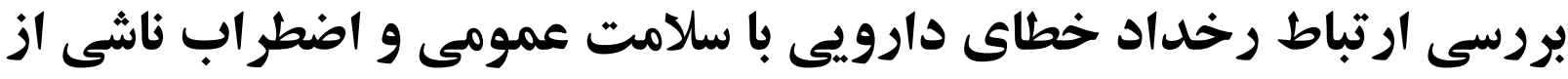

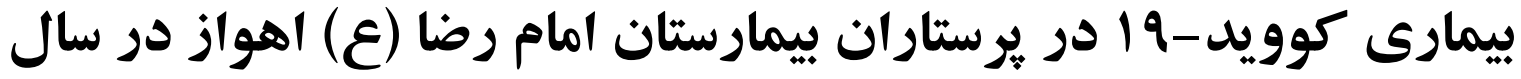

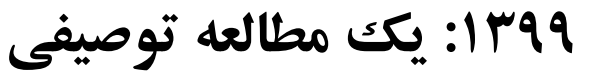

آرزو دستيار '، زهره كريميان كاكلكى

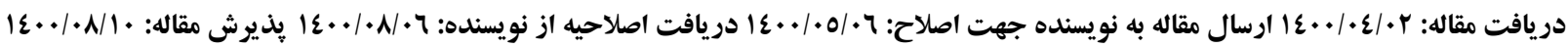

زمينه و هدف: خطاى دارويى با افزايش خستخى جسمى، اضطراب و استرس افزايش مىيابد. مطالعه حاضر با هدف تعيين ارتباط رخداد خطاى دارويى با سلامت عمومى و اضطراب ناشى از بيمارى كوويد-9 الدر يرستاران انجام شد.

مواد و روشها: اين مطالعه توصيفى بر روى •11 يرستار بيمارستان امام رضا (ع) اهواز در سال وجبا انجام شد. ابزار جمع آورى اطلاعات يرسشنامه سلامت عمومى \\ سؤالى Goldberg، يرسشنامه 1 أسؤالى اضطراب بيمارى كرونا و يرسشنامه خطاى دارويى VV آيتمى بود. معيارهاى ورود شامل حداقل يك شيفت كارى در ماه كذشته و تجويز دارو براى بيماران بود. اطلاعات با استفاده از آزمون همبستكى Pearson و رَرسيون خطى خند خانه تجزيهوتحليل شد.

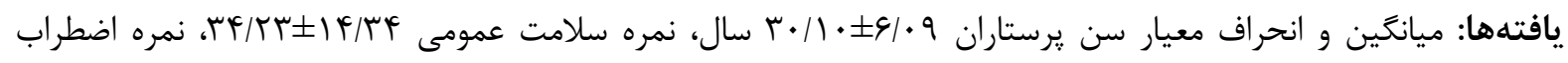

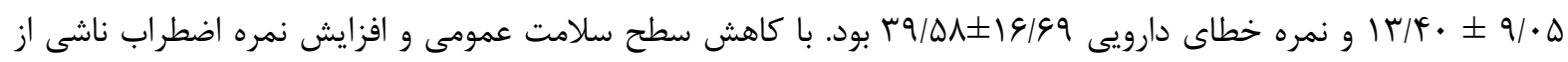

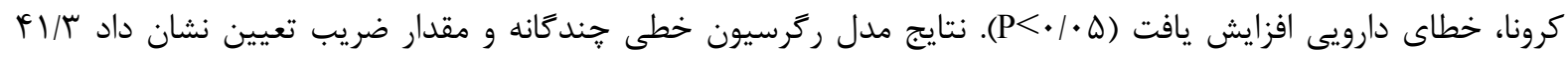
درصد از كل نمره خطاى دارويى با متغيرهاى ورودى مدل قابل تبيين است. يرستاران بخش كوويد-19 و و داراى سلامت

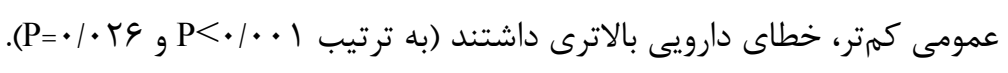

نتيجهَيرى: ارتباط بين مواجهه با بيماران كوويد-19، كاهش سلامت عمومى و افزايش اضطراب ناشى از كوويد-19 با افزايش رخداد خطاى دارويى، لزوم توجه مديران جهت برنامهريزى و اقدام براى بهبود سطح سلامت و كاهش اضطراب يرستاران را مىطلبد و لازم است در شرايط بحرانى مورد توجه قرار كيرد. وازههاى كليدى: خطاى دارويى، سلامت عمومى، اضطراب، كوويد-9 1، يرستار

1- دانشجوى ارشد مديريت خدمات بهداشتى درمانى، كروه بهداشت، دانشكده علوم يزشكى، واحد شهر كرد، دانشكاه آزاد اسلامى، شهر كرد، ايران

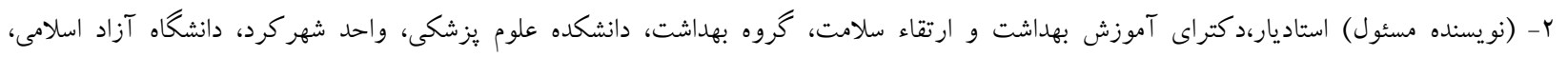
شهر كرد، ايران

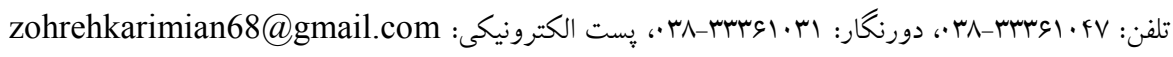


بيماران خاص، يرستاران را مستعد ابتلاء به انواع اختلالات

مقلهمه

روحى و روانى مى كند [V]. اين در حالى است كه كيفيت

بيمارى كوويد-19 يس از اولين ززارشات از موارد

مراقبت بهداشتى درمانى به ميزان زيادى به شرايط كارى و غيرطبيعى ينومونى در ووهان استان هوبى جين در دسامبر سلامت روان يرستاران بستخى دارد [^]. در شرايط بحرانى، افزايش سريع تعداد مبتلايان در إيدمىها، يزشكان و يرستاران را با حجم زيادى از بار كارى و مواجهه با عفونتهاى يرخطر روبهرو مىكند كه مىتواند منجر به مشكلات سلامت روان مانند اضطراب يا افسردگى شود [9]. مطالعه Chen و همكاران در تايوان حين همهَيرى SARS Severe acute respiratory syndrome)، نشان داد افرادى كه در واحدهاى با ريسك بالا كار مىكردند در مقايسه با ساير گروهها از اختلالات روانى بالاترى برخوردار بودند [. []. مطالعهاى ديكر توسط Wang و همكاران در جين نشان داد

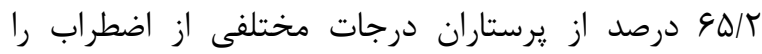
تجربه مى كنند [11]]. مطالعهاى ديگر توسط Liu و همكاران

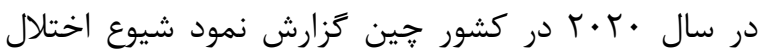
روانشناختى، علائم افسردگى و اضطراب به ترتيب ه/9 ا، |9 او

استرس و اضطراب، فشار كارى، كمبود نيرو و همرجنين نداشتن زمان لازم براى تجويز دارو، باعث كاهش ميزان توجه يرستاران و حفظ ايمنى بيماران، به عنوان يكى از اصول اساسى هـر نظـام بهداشـتى خواهد شد. عوامل متعددى ممكن است بر ايمنسى بيماران تأثيركذار باشند. اشتباهات دارويى صورت گرفته توسط گروههاى ارائه دهنده خدمت مىتواند يكى از مهمتـرين علـل زمينه سـاز بـروز سال 9 • r، باهسرعت توجه جامعه جهانى را به خود جلب نمود. يافتههاى إيدميولوزيك حاكى از انتقال سريع اين بيمارى از انسان به انسان بود [1]]. اين بيمارى تا تاريخ اب

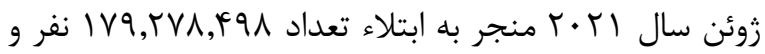

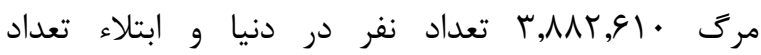
هץ گَترش و شيوع بسيار بالاى اين بيمارى، مرگومير در موارد شديد و نبود درمان تخصصى، اين بيمارى را تبديل به تهديد بزرگى براى سلامتى افراد جامعه و به خصوص اعضاى نظام سلامت مشغول در بيمارستانها نموده است. يرستاران و يزشكان هميشه در خط مقدم همدگيرىها به ارائه خدمت مشغول بوده [ب] و از آنجايى كه جهت انجام وظايف خود در تماس نزديك با بيماران مبتلا به كوويد-9 ا قرار دارند، در برابر ابتلاء به اين بيمارى آسيبٍذير هستند. بر اساس كَارشات تعداد زيادى از كاركنان بيمارستانها و بخش سلامت به اين بيمارى مبتلا شدهاند [\&]. در ايران نيز بر اساس گزارش معاون يرستارى وزارت بهداشت بيش از FD هزار يرستار به كرونا مبتلا شدهاند [ه]]. يرستاران از اعضاء مهمم سيستم خدمات سلامت كشورها هستند كه با ايفاى نقشهاى مختلف بر نظام سلامت تأثير مى گذارند [ع]. كار طولانى و برخورد با بيماران بدحال، ايفاى نقش حمايتى در ارتباط با بيماران و ارائه مراقبتهاى ويزه به 
تكميل نمودند و اطلاعات كاملاً محرمانه و يرسشنامهها كدبندى شده بود. اين مطالعه با كد اخلاق IR.IAU.SHK.REC.1399.062 در كميته اخلاق دانشگاه آزاد اسلامى واحد شهر كرد تأييد شده است.

اطلاعات متغيرهاى سن، جنسيت، وضعيت تأهل، مدرى تحصيلى، بخش محل كار، ارتباط داشتن با بيماران كوويد19، سابقه ابتلاء به كوويد-19 و سابقه ابتلاء به كوويد-19 در خانواده جمعآورى شد. در اين مطالعه، اطلاعات از طريق سه ״رسشنامه سلامت عمومى، اضطراب ناشى از كرونا و خطاى دارويى كه بهصورت الكترونيك طراحى و لينك آن براى : يرستاران ارسال شد، جمعآورى گرديد. نحوه تكميل يرسشنامهها بلصورت خودگزارشى بود.

جهت ارزيابى وضعيت سلامت عمومى از يرسشنامه سلامت عمومى Th سؤالى Goldberg (Questionnaire; GHQ يرسشنامه به بررسى وضعيت روانى فرد در يكماهه اخير مىيردازد و شامل نشانهايى مانند افكار و احساسات نابهنجار و جنبdهايى از رفتار قابل مشاهده است كه بر وضعيت اين جا و اكنون تأكيد دارد. يرسشنامه با سؤالهاى مربوط به علائم جسمانى شروع و با سؤالهايى كه بيشتر علائم روانيزشكى را مطرح مى كنند ادامه يِيدا مى كند. اين ״رسشنامه از جهار مقياس V سؤلى تشكيل شده است، بهطورى كه سؤالات 9-1 و سؤال 9 و مربوط به مقياس علائم جسمانى، سؤالات س V-V مربوط به مقياس علائم اضطرابى و

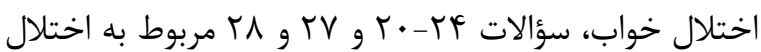

مشـكلات جـدى در سـلامت بيماران، افزايش مدت بسترى و هزينهها گـردد [سا []. تجويز دارو يكى از جنبdهاى اساسى و قابل توجه حرفه يرستارى است و اجراى دستورات دارويى جزء اصلى عملكرد يرستاران و بخش مهمى از فرآيند درمان و مراقبت از بيمار است. ازاينرو، بروز اشتباهات دارويى به عنوان يكى از شايعترين و مهمترين معضلات قابل توجه در نظامهاى بهداشتى، مىتواند تهديدى براى سلامت بيمار

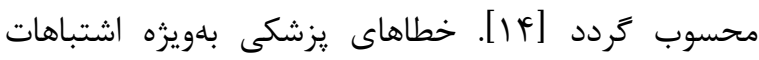
دارويى مىتوانند با خستگى جسمى، اضطراب و استرس افزايش يابند [ (اצ-1ه] و از طرفى بيمارى كوويد-19 نيز به عنوان بيمارى نويديد موجهايسى از ترس و اضطراب را افزايش مىدهد كه به نظر مىرسد باعث ايجاد اختلال گسترده در رفتار و بززيستى روانشناختى يرستاران مىشـود [IV]. ازاينرو، مطالعه حاضر با هدف تعيين ارتباط رخداد خطاى دارويى با سلامت عمومى و اضطراب ناشى از بيمارى كوويد-19 در يرستاران بيمارستان امام رضا (ع)

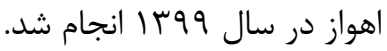

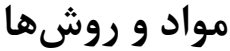

مطالعه حاضر بلهورت توصيفى در سال 99¥ا بر روى •ll نفر از ترستاران بيمارستان امام رضا (ع) اهواز كه بلصورت سرشمارى وارد مطالعه شدند، انجام شد. معيارهاى ورود به مطالعه شامل داشتن حداقل يك شيفت كارى در يك ماه كذشته و تجويز دارو براى بيماران و معيار خروج شامل يرستاران در مرخصى استعلاجى بود. تمامى شركت كنندكان رضايتنامه آكاهانه براى شركت در مطالعه را 
كرونا در مطالعه Alipour و همكاران با استفاده از بررسى روايى سازه تأييدى و تعيين ميزان برازش دادهها با مدل r عاملى ابزار و روش تحليل عاملى تأييد گرديد. يايايى يرسشنامه با استفاده از ضريب آلفاى كرونباخ 919 • ت تأييد

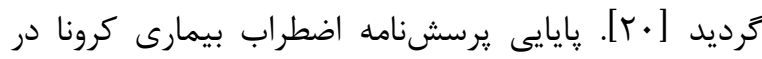
مطالعه حاضر با مقدار ضريب آلفاى كرونباخ يرسشنامه

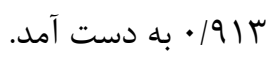

جهت بررسى خطاى دارويى از يرسشنامه استاندارد خطاى دارويى VV آيتمى استفاده شد. در اين برسشنامه اشتباهات دارويى با • ا سؤال، ترس از يِامدهاى گزارشدهى 9 سؤال، موانع مديريتى ززارشدهى ه سؤال و موانع فر آيند گزارشدهى r سؤال سنجيده مىشود. مقياس نمرهدهى به سؤالات بر اساس مقياس ليكرت ينجدرجهاى (بسيار

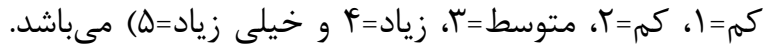
براى هر حيطه ميانگَين محاسبه شد. ميانگَين پايينتر در هر حيطه به معنى خطاى كمتر و ميانگين بالاتر به معنى خطاى بيشتر مىباشد. در مطالعه Jolaee و همكاران جهت بررسى روايى پرسشنامه خطاى دارويى، :رسشنامه توسط 19 نفر از اعضاء هيأت علمى دانشكده يرستارى و مامايى دانشگاه ايران بررسى و با استفاده از نظرات اصلاحى آنان، از نظر روايى محتوا مورد تأييد قرار گرفت. پايايى يرسشنامه با استفاده از روش آزمون مجدد بر روى •r نفر از يرستاران و با استفاده از مقدار ضريب همبستگى / / • بين نمرات دو آزمون، تأييد گرديد [آ[]. در مطالعه Alijanzadeh و همكاران، پيايايى ״رسشنامه با استفاده از ضريب آلفاى

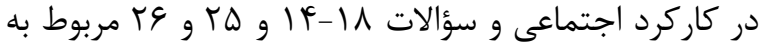
مقياس علائم افسردگى است. در اين مطالعه از شيوه

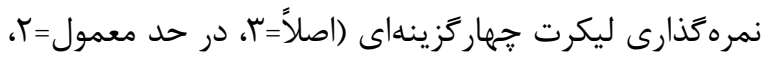
بيشتر از حد معمول=ا و خيلى بيشتر از حد معمول=•) بلمنظور نمرهذارى يرسشنامه استفاده شد و در نتيجه كل نمره يك فرد از صفر تا م متغير بود. كسب نمره كمتر در اين يرسشنامه بيانگر بهداشت روانى بهتر مىباشد. در مطالعه Nazifi و همكاران روايى يرسشنامه با استفاده از تحليل عاملى (Factor analysis) بررسى شد و نتايج نشان دهنده همبسته بودن خرد مقياسهاى اين خرسشنامه بوده و به طور نسبى مفهوم واحدى را اندازه مى ״ايايى :رسشنامه با استفاده از ضريب آلفاى كرونباخ بr9/. تأييد گرديد [19] مطالعه حاضر با مقدار ضريب آلفاى 19/9/ • به دست آمد. وضعيت اضطراب يرستاران با استفاده از گرسشنامه خودارزيابى مقياس اضطراب بيمارى كرونا ( Corona (Disease Anxiety Scale; CDAS

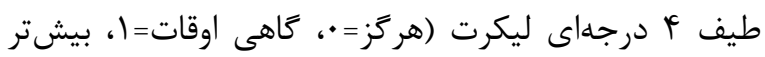

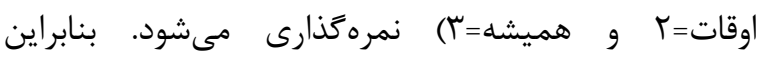
بيشترين و كمترين نمره افراد پاسخ دهنده در اين يرسشنامه · تا DF است. نمرات بالاتر در اين يرسشنامه نشان دهنده سطح بالاترى از اضطراب در افراد است. نسخه نهايى اين ابزار داراى \1 گويه و r مؤلفه يا عامل است. Fويههاى 9-1 علائم روانى و گويههاى 11-- 1 علائم جسمانى را مىسنجد. روايى پرسشنامه اضطراب بيمارى 
بود. از نظر توزيع جنسى، V/9 درصد (V^ نفر) يرستاران شركت كننده در مطالعه زن، از نظر سطح تحصيلات / درصد (r9 نفر) يرستاران داراى مدرك كارشناسى و از نظر وضعيت تأهل هF/D درصد ( •ع نفر) يرستاران متأهل بودند. نتايج مطالعه نشان داد \&/rr درصد (צr نفر) يرستاران در بخش اورزانس، • | درصد (1 (1 نفر) در بخش جراحى، ع/r| درصد (ها نفر) در بخش كوويد-19 و •F درصد (FF نفر) در ساير بخشهاى بيمارستان مشغول به كار بودند. از نظر وضعيت مواجهه با بيماران مبتلا به كوويد-9 |، VN/T درصد (19) نفر) يرستاران سابقه مثبت داشتند. از نظر وضعيت ابتلاء به كوويد-9 1، اغلب يرستاران سابقه ابتلاء نداشتند و

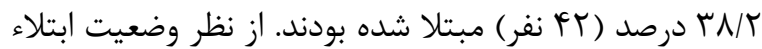
به كوويد-19 در بستگان، نتايج نشان داد 9N/T درصد (VD نفر) از بستخان يرستاران به بيمارى مبتلا شدهاند.
كرونباخ ع1/· تأييد گرديد [זr]. در مطالعه حاضر مقدار ضريب آلفاى كرونباخ يرسشنامه استاندارد خطاى دارويى 1999/• محاسبه شده است.

اطلاعات يس از جمعآورى وارد نرمافزار SPSS نسخه 1 نآ شده و با استفاده از آزمون همبستخى Pearson جهت بررسى ارتباط بين سلامت عمومى، اضطراب ناشى از كرونا و رخداد خطاى دارويى و آناليز ركرسيون خطى جندكانه جهت بررسى متغيرهاى تأثير گذار بر نمره خطاى دارويى مورد تجزيهوتحليل قرار گرفت. سطح معنىدارى در آزمونها

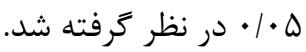
نتايج در مطالعه حاضر تعداد •11 يرستار شركت كردند. ميانگين و انحراف معيار سنى يرستاران شركت كننده در

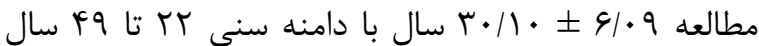
جلدول ا - شاخصهاى توصيفى نمره سلامت عمومى، اضطراب ناشى از كرونا و خطاى د/رويى و ابعاد آنها در يرستاران بيمارستان /مام رضا (ع) /هواز دو سال 199

\begin{tabular}{|c|c|c|c|c|c|}
\hline 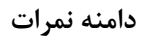 & 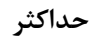 & 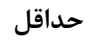 & انحر اف معيار 土 ميانگين & 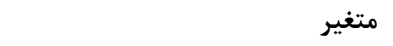 & برسش نامه \\
\hline rI-e. & 19 & . & $q / V r \pm r / f r$ & بعد علائم جسمانى & \multirow{5}{*}{ لامت عمومى } \\
\hline$\langle i-\cdot$ & TI & . & $1 \cdot 19 \Delta \pm \Delta / T V$ & بعد علائم اضطرابى و اختلال خواب & \\
\hline$r I_{-}$ & 11 & · & سr/ & بعد اختلال در كاركرد اجتماعى & \\
\hline rI-• & 10 & 1 & $V / 9 \mid \pm r / 19$ & بعد علائم افسردگى & \\
\hline$\Lambda \boldsymbol{F}_{-} \cdot$ & $9 \wedge$ & $\checkmark$ & $r F / T r \pm I F / r F$ & نمره كل سلامت عمومى & \\
\hline rV-• & rut & . & $q / \Lambda F \pm \Delta / \mathcal{F} \Delta$ & علائم روانى اضطراب & \\
\hline$r V_{-} \cdot$ & 11 & . & $q / V r \pm r / 4 r$ & علائم جسمانى اضطراب & \\
\hline$\Delta F_{-} \cdot$ & rᄉ & . & $\mid r / \varphi \cdot \pm q / \cdot \Delta$ & نمره كل اضطراب & \\
\hline$\Delta \cdot-1 \cdot$ & Tr & $1 \cdot$ & $14 / 19 \pm f / 91$ & اشتباهات دارويى & \multirow{5}{*}{ خطاى دارويى } \\
\hline$f \Delta-q$ & \&) & 9 & $\mid F / \& V \pm V / q \varphi$ & ترس از يِيامدهاى گزارش دهى & \\
\hline$r \Delta-\Delta$ & tr & $\Delta$ & $V / \Delta V \pm r / q V$ & وجود موانع مديريتى گزارش دهى & \\
\hline $1 \Delta-r$ & ir & r & $r / T \Delta \pm r / T r$ & موانع فرآيند كزارشدهىى & \\
\hline$I T \Delta-r V$ & 1.9 & TV & $r q / \Delta \Lambda \pm 19 / 99$ & نمره كل خطاى دارويى & \\
\hline
\end{tabular}


ميزان سطح خطاى دارويى كم در يرستاران مىباشد (جدول

در جدول r، نتايج مربوط به همبستخى بين نمره سلامت عمومى، اضطراب ناشى از كرونا و رخداد خطاى دارويى يرستاران نشان داده شده است. اين يافتهها نشان مىدهد ارتباط بين نمره خطاى دارويى در يرستاران تقريباً در تمامى موارد (بهجزء ارتباط با بعد موانع مديريتى گزارشدهى) ارتباط مثبت و معنى دارى با نمره سلامت عمومى و اضطراب ناشى از كرونا دارد (ه • P>/P)، بلطورى كه با افزايش نمره سلامت عمومى (كه حاكى از افت ميزان سلامت مىباشد) و افزايش نمره اضطراب ناشى از كرونا، نمره خطاى دارويى

$$
\text { يرستاران نيز افزايش يافته است (جدول ؟). }
$$

در جدول ا، ميانگين و انحراف معيار، مقدار حداقل و حداكثر و دامنه نمرات سلامت عمومى، اضطراب ناشى از كرونا و خطاى دارويى يرستاران بيمارستان امام رضا (ع) اهواز در رِاندمى بيمارى كوويد-19 نشان داده شده است. همانطور كه ملاحظه مى گردد ميانگين و انحراف معيار نمره سلامت عمومى يرستاران توجه به نمره ايده آل برسشنامه سلامت عمومى، در حد مطلوبى مىباشد. ميانخين و انحراف معيار نمره اضطراب

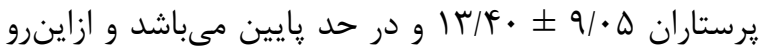
به نظر مىرسد سطح اضطراب در يرستاران در حد پايينى مىباشد. همزجنين ميانخين و انحراف معيار نمره خطاى دارويى در يرستاران 19/99 جدول r - ضريب همبستكى بين سلامت عمومى، اضطراب ناشى از كرونا و رخداد خطاى دارويى در برستاران بيمارستان

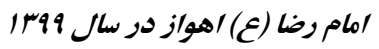

\begin{tabular}{|c|c|c|c|c|}
\hline \multicolumn{2}{|c|}{ اضطراب ناشى از كرونا } & \multicolumn{2}{|c|}{ سلامت عمومى } & \multirow[b]{2}{*}{ متغير } \\
\hline مقدار P P P & ضريب همبستكى & مقدار P P P & ضر يب همبستكى & \\
\hline$\cdot 1 \cdot .1$ & $\cdot$. & $<\cdot|\cdot \cdot|$ & $\cdot 1499$ & اشتباهات دارويى \\
\hline$\cdot 1 . .1$ & $\cdot / r \cdot 1$ & $\cdot / \cdot r$ & $\cdot / T R T$ & ترس از بيامدهاى تزارشدهى \\
\hline$\cdot / \cdot \Delta$ & $\cdot / K \& V$ & $\cdot / 1 \Delta V$ & $\cdot 11$ He & وجود موانع مديريتى كزارشدهى \\
\hline$\cdot 1 . .1$ & • MTS & $\cdot / \cdot r V$ & .1199 & موانع فر آيند كزارشدهى \\
\hline$<\cdot 1 \cdot \cdot 1$ & . &.$/ \cdot r$ & $\cdot / r 91$ & نمره كل خطاى دارويى \\
\hline
\end{tabular}

با استفاده از Normal P-P Plot و تجمع نقاط حول خط هi درجه تأييد گرديد. نتايج مربوط به عدم وجود همخطى بين متغيرهاى پيشبين، با استفاده از (Collinearity) شاخص Eigenvalue = Condition Index = r/\&ᄉ)
جدول سا، نتايج آناليز رگرسيون خطى جندكانه براى ״يشبينى كنندهاى نمره خطاى دارويى يرستاران را نشان مىدهد. بررسى پيشفرض نرمال بودن متغير خطاى دارويى با استفاده از بررسى نمودار هيستوگرام و وجود شكل توزيع نرمال انجام كرفت. ييشفرض استقلال خطاها با آزمون و و پيشفرض توزيع نرمال خطاها 
نشان مىدهد يرستارانى كه با بيماران مبتلا به كوويد-19 در

ارتباط بودند، به طور متوسط IV/9YA نمره خطاى دارويى

بالاترى داشتند. همرجنين با افزايش يك نمره سلامت

عمومى يرستاران و در نتيجه كاهش سطح سلامت عمومى،

ميانگين نمره خطاى دارويى يرستاران به اندازه سه//

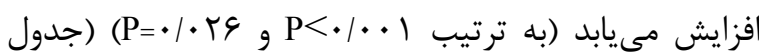

()
مقدار ضريب تعيين (R²) مدل رگرسيون نشان مىدهد או I درصد از كل نمره خطاى دارويى با متغيرهاى ورودى به مدل قابل تبيين است. از بين متغيرهاى ورودى به مدل با روش Enter كه در جدول ززارش شده است، فقط ارتباط متغيرهاى كار در بخش كوويد-19 و نمره كل سلامت عمومى، با خطاى دارويى از نظر آمارى معنىىار مىباشند. ضرايب بتا استاندارد نشده متغير كار در بخش كوويد-19 جدول سـ متغيرهاى تأثيركذار بر نمره خطاى دارويى با استفاده از ملدل ركوسيون خطى جندكانه در برستاران بيمارستان /مام رضا (ع) اهواز در سال 1499

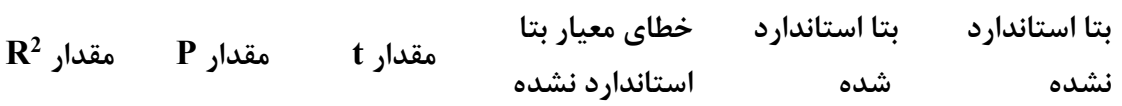

\begin{tabular}{|c|c|c|c|c|c|}
\hline $.1 \cdot .9$ & T/ATD & $|r / 1| 9$ & --- & $T F / T \Delta \Delta$ & مقدار عدد ثابت (o及) \\
\hline$\cdot / V V r$ & $\cdot / r q \cdot$ & $\cdot / 499$ & $\cdot / \cdot r \Lambda$ & $\cdot / \cdot V V$ & سن (سال) \\
\hline.$/ I H V$ & $-1 / 499$ & (T/T & $-\cdot / 1 \mathrm{rV}$ & $-\Delta / / \cdot 10$ & زنسيت \\
\hline$\cdot \mid \Delta F F$ & $\cdot 19 \cdot 9$ & $F / \cdot V \Delta$ & $\cdot 1 \cdot \Delta \Delta$ & $r / F \wedge 1$ & سطح تحصيلات \\
\hline \multirow[t]{2}{*}{ •/lr. } & $-1 / \Delta T \Lambda$ & $r / 990$ & $-\cdot / 1 r V$ & $-F / \Delta V V$ & متأهل نسبت تأهل \\
\hline & & & & & بخش محل كار \\
\hline$\cdot 1 \cdot \Delta q$ & $-1 / 911$ & $\Delta / I \vee \Delta$ & $-.11 \vee 9$ & $-9 / \wedge \wedge \vee$ & بخش جراحى به اورزانس \\
\hline. $\mid 991$ & $\cdot \mid \cdot \uparrow \wedge$ & F/VDT & $\cdot 1 \cdot \cdot \Delta$ & . & بخش ويزه به به اورزانس \\
\hline$<\cdot 1 \cdot \cdot 1$ & r/AVF & F/GTV & $\cdot / r V \cdot$ & IV/9TA & بخش كوويد -19 \\
\hline (ITI &.$- / 991$ & T/VTG & .111 & -r/VT. & ساير بخش ها \\
\hline ITI & $1 / T \cdot \Delta$ & $r / V V r$ & س & $F / \Delta F \Delta$ & ارتباط با بيماران مبتلا به كوويد-19 \\
\hline$\cdot / V F D$ & . & $r / r \Delta F$ & $\cdot|\cdot r|$ & $1 / .91$ & ابتلاء به بيمارى كوويد-19 \\
\hline$\cdot / V A V$ & $-\cdot / 49 \mathrm{~V}$ & $\Gamma / 1 \wedge \Delta$ & $-.1 \cdot 4 Q$ & $-.194 \Delta$ & ابتلاء بستكًان به بيمارى كوويد -19 \\
\hline$\cdot 1 \cdot$ Ts & $T / T \Delta V$ &.$/ 11 r$ & $\cdot / T I V$ & $\cdot / T \Delta K$ & نمره كل سلامت عمومى \\
\hline.$/ 1 r 9$ & س & $\cdot / 1 \wedge$. & $\cdot / 10$ & - ITVG & نمره كل اضطراب \\
\hline
\end{tabular}

متغير 
خانوادَى و اجتماعى را بر عهده بخيرد و از انجام درست آن

ناتوان خواهد بود [YF]. ساعات كار طولانى، فقدان حمايت، بار كارى سنخين، خشونت از سوى بيماران، كاركنان ناكافى، منابع ناكافى، فقدان احترام، عدم دخالت در تصميمگيرىها و عدم وجود تجهيزات كافى و توقعات زياد از برستاران باعث بيمارىهاى روانشناختى هم جون استرس، اضطراب، خواب ناكافى در يرستاران مىشود [1/]. البته نكته مهمى كه در يافتههاى حاصل از مطالعه حاضر نهفته اين كه اترجه بيمارى كوويد-19 بهعنوان يك معضل جهانى و رو به يِيشرفت هم קنان بعد از حدود يك سال باقىمانده اما تأثير طولانىمدت آن بر سطح سلامت عمومى برستاران، با توجه به اين كه اين مطالعه نيز يس از حذشت حدود يك سال از شروع ياندمى انجام شده، كاهشيافته است. جرا كه در ابتداى مواجهه با يك بحران افزايش تنشها و استرس و نكَرانى موضعى قابل توجيه است [IV] كه پِ از كذشت مدتى تأثيرات روانشناختى آن مىتواند با توجه به افزايش سطح آتاهى و دانش يرستاران در برخورد با بيمارى و بيماران كاهشيافته باشد. نتايج مطالعه حاضر همجنين نشان داد ميانگين نمره اضطراب يرستاران در مطالعه حاضر در حد يايينى بود. در همين راستا نتايج مطالعه Abadi و همكاران نشان داد افسردگى، اضطراب و استرس يرستاران در ياندمى كوويد-19 در حد متوسط بود [^ץ]. نتايج مطالعه Asadi و همكاران نشان داد نمره كلى اضطراب كرونا در يرستاران مورد مطالعه

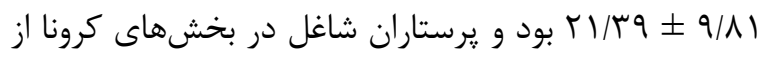

همانطور كه نتايج مطالعه نشان داد ميانكين نمره سلامت عمومى يرستاران در حد مطلوبى بود. در همين راستا مطالعه Niazi و همكاران نشان داد وضعيت سلامت عمومى ڤِستاران در حد مطلوبى است [سr]. در مطالعه ديغرى كه توسط Maghsoodi و همكاران انجام شد نشان داد تنها V/T درصد يرستاران اختلال سلامتى داشتند و بيشتر يرستاران در وضعيت سلامتى خوب بودند [Cr]. از طرف ديگر نتايج مطالعه Dehghankar نشان داد كه سلامت يرستاران ايرانى در وضعيت مناسبى قرار ندارد و افسردگى و اختلالات عملكردى در يرستاران بالا است [هץ]. مطالعه و و همكاران نشان داد يرسـتاران در وضعيت مشكوك به اختلال در سلامت عمومى و سطح استرس بالايى قرار دارند [عץ]. در مطالعه ديخرى كه Najafi و همكاران بر روى :رستاران شاغل در بيمارستانهاى آموزشى زاهدان انجام دادند مشخص شد نزديك به نيمى از يرستاران از سلامت عمومى نامطلوب و كيفيت زندگى كارى متوسط برخوردار هستند [rV]]. همانطور كه ملاحظه مى كردد كزارشات متفاوتى از وضعيت سلامت عمومى يرستاران در مطالعات خاطر نشان شده است، اما آنجه در اين زمينه اهميت بالايى دارد اينكه يرستارى يكى از رشتههاى اصلى مراقبت و يرستار سالم از عوامل اصلى جهت ارتقاء كيفيت مراقبت است. بين يرستارى سالم و ارتقاء سلامت ارتباط مثبت و قوى برقرار است و بدون ترديد كسى كه دجار اختلال در سلامتى است، نمىتواند تعهدات و الزامات فردى، 
[عץ]. برخى از عوامل استرسزا مانند بيمارىها از جمله كوويد-19 مىتواند موجب برانگيختن اضطراب و نكرانى براى سلامتى شود و خودكارآمدى را در كادر درمانى درگير بيماران كوويد-19 تحت تأثير قرار دهد [اب]]. در نهايت نتايج مطالعه در بررسى ارتباط بين خطاى دارويى در يرستاران با سلامت عمومى و اضطراب ناشى از كرونا نشان داد با افزايش سطح سلامت عمومى و افزايش نمره اضطراب ناشى از كرونا، ميزان نمره خطاى دارويى نيز افزايش يافت، اما نتايج مربوط به بررسى متغيرهاى تأثير گذار بر نمره خطاى دارويى يرستاران نشان داد تنها متغيرهاى كار در بخش كوويد-19 و كاهش سطح سلامت عمومى با خطاى دارويى مرتبط مىباشند. يرستارانى كه در ارتباط با بيماران مبتلا به كوويد-19 بودند نمره خطاى دارويى بالاترى داشتند. همرجنين : يرستارانى كه سلامت عمومى كمترى داشتند خطاى دارويى بالاترى نيز گزارش نمودند. نتايج مطالعه Nurmeksela و همكاران نشان داد ارتباط معنىدارى بين محتواى كار يرستار و خطاهاى دارويى وجود دارد [rr]. خستخى ناشى از كار اضافى و نداشتن فرصت كافى، تراكم زياد كار و ميزان سروصداى محيطى و كمبود تعداد نيروى يرستار و مشكلات روحى و روانى يرستاران از عوامل مؤثر بر بروز خطاهاى دارويى گرستاران مىباشد [ع|-ها]. مؤسسه The Institute for Safe ) روشاى دارويى ايمن (Medication Practices از خطاى دارويى در ارتباط با بيماران مبتلا به كوويد-19 دريافت نموده است كه به علت برجسب اشتباه دارو و
اضطراب متوسط رنج مىبرند [•r]. نتايج مطالعه Xiao و همكاران نشان داد سطوح حمايت اجتماعى كادر درمان بيمارى كرونا بلطور معنىدارى و بلهورت منفى با درجه اضطراب و استرس كادر درمان همبسته است [اب]. نتايج مطالعه Holmes و همكاران نشان داد جمعيت بزرگى از متخصصان مراقبتهاى بهداشتى سطح قابل توجهى از اضطراب، افسردىى و بىخوابى را در طول بيمارى كوويد-19

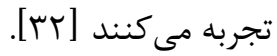
بررسىهاى اخير و گسترده بر روى افراد مستعد ابتلاء به عفونت كرونا ويروس ازجمله كاركنان زيشكى ميـزان شـيوع اسـترس آسيبزا را أ/ V درصـد، افسـردكى V/ • ه درصد و اضطراب FF/V درصد Fزارش دادند [سب]. در مرحله اوليه شيوع كرونا ويروس در جين، بيش از نيمى از پاسخدهندكان تأثير روانشناختى را شـديد تا متوسط و حدود يكسوم اضطراب متوسط تا شديد ززارش كردند [بr]]. يافتههاى قبلى ارتباطات واضحى بين بيمارىهاى همهَير بـا اضطـراب و افزايسش علائمم استرس نكرانىهاى آلودگى، اضطراب سلامتى، اسـترس يسس از سانحه و خودكشى را نشان داده است. ايسن يافتهها بخشى از رونـد نكَران كننده اضطـراب كرونــا اسـت كـه در بيـن مـردم يافـت مىشود تــا جايسى كــهـ بعضى از مـردم از ترس ابتلاء به بيمارى اقدام به

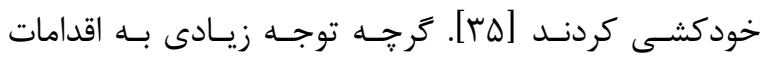
مربوط به شناسايى افراد مبتـلا به عفونت كرونا ويـروس شـده اسـت، امـا شناســيى نيازهــاى سـلامت روان افـراد تحـت تأثير ايـن بيمـارى همهَّير ناديـده كرفته شده اسـت 
كرونا در يرستاران، باعث افزايش ميزان خطاى دارويى مىشود. از اينرو لازم است برنامهريزى لازم جهت ارتقاء سطح سلامت و كاهش اضطراب يرستاران در شرايط بحرانى مورد توجه ويزه قرار گيرد، جرا كه روند رو به گسترش بيمارى كوويد-9 ا، بار كارى و مشكلات سلامت روان مانند اضطراب و افسردگى را افزايش داده و با ادامه اين بحران، خستكى و فرسودى كادر درمان و در بيى آن كاهش كيفيت خدمات و افزايش ميزان خطاى دارويى دور از انتظار نيست. لذا براساس يافتههاى يزوهش حاضر، از لحاظ كاربردى برگزارى كاركاههاى آموزشى جهت بهبود سلامت عمومى و كاهش سطح اضطراب براى يرستاران شاغل در بيمارستانها در مواجهه با شرايط بحرانى و ويزه توصيه مى تشكر و قدردانى مقاله حاضر حاصل پايانامه دانشجويى مقطع كارشناسى ارشد دانشعاه آزاد اسلامى واحد شهركرد مىباشد. بدين وسيله از اساتيد محترم و مسئولان يزوهشى دانشعاه آزاد واحد شهركرد كه در تمامى مراحل تصويب، تأييد، انجام و ارتقاء كيفى اين يزوهش، با محقق همكارى داشتند، تشكر مىنماييه. از مديران و يرستاران بيمارستان امام رضا (ع) اهواز كه با شركت در مطالعه و تكميل :رسشنامه، نويسندًان اين مقاله را مساعدت

$$
\text { نمودند، تشكر و قدردانى بهعمل مى آيد. }
$$

مواردى به علت تغييرات محل كار يرستاران، عدم توانايى يرستار در سنجش بيمار و در نتيجه استفاده از دوز داروى نادرست كزارش شده است [^ץ؟]. از اينرو لازم است با توجه به شرايط خاصى كه با بيدايش بيمارى كوويد-19 ايجاد شده و تبعات نامطلوبى كه براى افراد جامعه و به خصوص يرستاران خط مقدم مبارزه با اين بيمارى در يى داشته، اقدامات لازم جهت افزايش سطح سلامت و كاهش اضطراب و استرس آنها طراحى و در مطالعات آتى بررسى گردد. در يايان خاطر نشان مىسازد محدوديتى كه وجود داشت انجام مطالعه در يك بيمارستان شهر اهواز مىباشد كه براى تعميم نتايج لازم است مطالعه در بيمارستانهاى بيشتر و مناطق مختلف انجام شود. همرجنين جهت رعايت يروتكلهاى بهداشتى و جلوكيرى از اشاعه بيمارى كوويد9 19، تكميل يرسشنامهها به صورت الكترونيك انجام شد كه براى كسب اطلاعات دقيقتر، پيشنهاد مىشود در يزوهشهاى آتى از روشها و ابزارهاى ديگرى نظير مصاحبه بالينى استفاده كردد. همجزنين از آنجايى كه گزارش موارد خطاى دارويى ممكن است دجار كم گززارشدهى گردد، لازم است در يزوهشهاى آتى مورد توجه قرار گيرد.

\section{نتيجه گيرى}

نتايج مطالعه حاضر نشان داد مواجهه با بيماران كوويد-

19، كاهش سطح سلامت عمومى و افزايش اضطراب ناشى از 


\section{References}

[1] Organization WH. Clinical management of severe acute respiratory infection when novel coronavirus ( 2019-nCoV) infection is suspected: interim guidance, 28 January 2020. World Health Organization; 2020.

[2] Worldometer. COVID-19 Coronavirus Pandemic: Worldometer; 2020 [Available from: https://www.worldometers.info/coronavirus/?utm_cam paign=homeAdvegas 1 .

[3] Gao J, Zheng P, Jia Y, Chen H, Mao Y, Chen S, et al. Mental Health Problems and Social Media Exposure During COVID-19 Outbreak. PLoS One 2020; 15 (4): e0231924.

[4] Ehrlich H, McKenney M, Elkbuli A, . Protecting our healthcare workers during the COVID-19 pandemic. Am J Emerg Med 2020; 1 (38): 1527-8.

[5] Webda. COVID-19 morbidity in Iranian nurses 2021 [Available from: https://yun.ir/pgcoob.

[6] Mileski M, Pannu U, Payne B, Sterling E, McClay R. The impact of nurse practitioners on hospitalizations and discharges from long-term nursing facilities: a systematic review. Healthcare 2020; 8 (2): 114-34.
[7] Mehrabi T, Ghazavi Z. Health assessment of female nurses of Isfahan university of Medical Science. $J$ of hygiene and health 2003; 1 (2): 1-5.

[8] Su T-P, Lien T-C, Yang C-Y, Su YL, Wang J-H, Tsai S-L, et al. Prevalence of psychiatric morbidity and psychological adaptation of the nurses in a structured SARS caring unit during outbreak: A prospective and periodic assessment study in Taiwan. $J$ Psychiatr Res 2007; 41 (1-2): 119-30.

[9] Kang L, Li Y, Hu S, Chen M, Yang C, Yang BX, et al. The mental health of medical workers in Wuhan, China dealing with the 2019 novel coronavirus. The Lancet Psychiatry 2020; 7 (3): e14.

[10] Chen C-S, Wu H-Y, Yang P, Yen C-F. Psychological distress of nurses in Taiwan who worked during the outbreak of SARS. Psychiatric Services 2005; 56 (1): 76-9.

[11] Wang L-Q, Yu Y, Wang X-Q, Dong S-F, Qi B. Anxiety of Nurses Working in SARS Wards and Influencing Factors. Nursing $J$ of Chinese People's Liberation Army 2003; 8: 1-2. 
[12] Liu Z, Han B, Jiang R, Huang Y, Ma C, Wen J, et al. Mental Health Status of Doctors and Nurses During COVID-19 Epidemic in China. Ann Glob Health 2020; 86 (1): 128-40.

[13] Jaafaripooyan E, Madady Z. Nursing Medication Errors: Causes and Solutions (A Review Study). Hospital 2015; 14 (3): 101-10.

[14] Alrabadi N, Shawagfeh S, Haddad R, Mukattash T, Abuhammad S, Al-rabadi D, et al. Medication errors: a focus on nursing practice. $J$ of Pharmaceutical Health Services Research 2021; 12 (1): 78-86.

[15] Melnyk BM, Orsolini L, Tan A, Arslanian-Engoren C, Melkus GDE, Dunbar-Jacob J, et al. A national study links nurses' physical and mental health to medical errors and perceived worksite wellness. J Occup Environ Med 2018; 60 (2): 126-31.

[16] Mohebbifar R, Bay V, Alijanzadeh M, Asefzadeh S, Mohammadi N. Factors influencing the incidence of medication errors: The perspective of nurses in teaching hospitals. PAYESH 2015; 14 (4): 435-42.

[17] Aziziaram S, Basharpoor S. The role of rumination, emotion regulation and responsiveness to stress in predicting of Corona anxiety (COVID-19) among nurses. Quarterly J of Nursing Management 2020; 9

(3): $8-18$.

[18] Goldberg D. The Detection of Psychiatric Illness by Questionnaire. Maudsley Monograph Oxford: Oxford University Press; 1972.

[19] Nazifi M, Mokarami H, Akbaritabar A, Faraji Kujerdi M, Tabrizi R, Rahi A. Reliability, Validity and Factor Structure of the Persian Translation of General Health Questionnire (GHQ-28) in Hospitals of Kerman University of Medical Sciences. JABS 2014; 3 (4): $336-42$.

[20] Alipour A, Ghadami A, Alipour Z, Abdollahzadeh H. Preliminary Validation of the Corona Disease Anxiety Scale (CDAS) in the Iranian Sample. $J$ of health psychology 2020; 8 (4): 163-75.

[21] Jolaee S, Hajibabaee F, Peyravi H, Haghani H. Nursing medication errors and its relationship with work condition in Iran University of Medical Sciences. Medical Ethics and History of Medicine 2009; 3 (1): $65-76$.

[22] Alijanzadeh M, Mohebifar R, Azadmanesh Y, Faraji M. The Frequency of Medication Errors and Factors Influencing the Lack of Reporting Medication Errors in Nursing at Teaching Hospital of Qazvin University 
of Medical Sciences, 2012. J of Health 2015; 6 (2): 169-79.

[23] Niazi M, Menati R, Delpisheh A, Menati S, Kassani A. The Association between general health and emotional intelligence in the nurses of Ilam province. Sadra Medical Journal 2015; 3 (3): 179-90.

[24] Maghsoodi S, Hesabi M, Emami sigaroudi A, Kazemnejad leili E, Monfared A. General health and related factors in employed nurses in MedicalEducational Centers in Rasht. JHNM 2015; 25 (1): 63 72.

[25] Dehghankar L. General health of Iranian registered nurses: A cross sectional study. IJNRHN 2016; 3 (2): $105-8$.

[26] Barzideh M, Choobineh A, Tabatabaei S. Job stress dimensions and their relationship to general health status in nurses. Occupational Medicine 2012; 4 (3): $17-27$.

[27] Najafi F, Kermansaravi F, Gangoozehi E. The Relationship between General Health and Quality of Work Life of Nurses Working in Zahedan Teaching Hospitals. Iranian $J$ of Rehabilitation Research in Nursing 2018; 4 (2): 53-9.
[28] de Oliveira Guimarães AL, Andres Felli VE. Notification of health problems among nursing workers in university hospitals. Revista brasileira de Enfermagem 2016; 69 (3): 507-14.

[29] Abadi TSH, Askari M, Miri K, Nia MN. Depression, stress and anxiety of nurses in COVID-19 pandemic in Nohe-Dey Hospital in Torbat-e-Heydariyeh city, Iran. J of Military Med 2020; 22 (6): 526-33.

[30] Asadi N, Salmani F, poorkhajuie s, mahdavifar m, royani z. Investigating the Relationship Between Corona Anxiety and Nursing Care Behaviors Working in Coronary Referral Hospitals. IJPCP 2020; 26 (3): 306-19.

[31] Xiao H, Zhang Y, Kong D, Li S, Yang N. The effects of social support on sleep quality of medical staff treating patients with coronavirus disease 2019 (COVID-19) in January and February 2020 in China. Med Sci Monit 2020; 26: e923549-1.

[32] Holmes EA, O'Connor RC, Perry VH, Tracey I, Wessely S, Arseneault L, et al. Multidisciplinary research priorities for the COVID-19 pandemic: a call for action for mental health science. The Lancet Psychiatry 2020; 7 (6): 547-60. 
[33] Liu S, Yang L, Zhang C, Xiang Y-T, Liu Z, Hu S, et al. Online mental health services in China during the COVID-19 outbreak. The Lancet Psychiatry 2020; 7 (4): e17-e8.

[34] Wang C, Pan R, Wan X, Tan Y, Xu L, Ho CS, et al. Immediate psychological responses and associated factors during the initial stage of the 2019 coronavirus disease (COVID-19) epidemic among the general population in China. Int $J$ Environ Res Public Health 2020; 17 (5): 1729.

[35] Goyal K, Chauhan P, Chhikara K, Gupta P, Singh MP. Fear of COVID 2019: First suicidal case in India! Asian J of psychiatry 2020; 49: 101989.

[36] Xiang Y-T, Yang Y, Li W, Zhang L, Zhang Q, Cheung $\mathrm{T}$, et al. Timely mental health care for the
2019 novel coronavirus outbreak is urgently needed. The Lancet Psychiatry 2020; 7 (3): 228-9.

[37] Nurmeksela A, Mikkonen S, Kinnunen J, Kvist T. Relationships between nursing management, nurses' job satisfaction, patient satisfaction, and medication errors at the unit Level: A correlational study. Research Square 2020; 1 (1): 1-22.

[38] Gilead S, . COVID-19-related medication errors: The Institute for Safe Medication Practices; 2021 [Available from: https://www.pharmacist.com/article/ covid-19related-medication-errors. 


\title{
Association of Medication Error Occurrence with General Health and Anxiety Caused by Covid-19 Disease in Nurses of Imam Reza Hospital of Ahvaz in 2020: A Descriptive Study
}

\author{
A. Dastyar $^{1}, \underline{\text { Z. Karimiankakolaki }^{2}}$
}

\section{Received: 23/06/21 Sent for Revision: 28/07/21 Received Revised Manuscript: 28/10/21 Accepted:01/11/21}

Background and Objectives: Medication error rises with an increase in physical fatigue, anxiety, and stress. The aim of this study was to investigate the association of medication error occurrence with general health and anxiety caused by Covid- 19 disease in nurses.

Materials and Methods: This descriptive study was conducted on 110 nurses of Ahvaz Imam Reza Hospital in 2020 Data collected with Goldberg 28-item General Health Questionnaire, 18-item Corona Disease Anxiety Scale, and 27item Medication Error Questionnaire. Inclusion criteria were having at least one work shift in the past month and prescribing medication to patients. Data were analyzed using Pearson's correlation test and multiple linear regression.

Results: The mean age of nurses was $30.10 \pm 6.09$ years. The mean score of general health of nurses was $34.23 \pm 14.34$, the mean score of anxiety was $13.40 \pm 9.05$, and the mean score of medication error was $39.58 \pm 16.69$. Medication error increased as general health decreased and Covid-19 anxiety score increased $(p<0.05)$. The results of the multiple linear regression model showed that based on the coefficient of determination $41.3 \%$ of the total drug error score can be explained by the model input variables. Nurses in Covid-19 ward and with lower general health score also had higher medication error $(\mathrm{p}<0.001$ and $\mathrm{p}=0.026$, respectively).

Conclusion: The association of exposure to Covid-19 patient, decreased general health, and increased anxiety caused by Covid-19 disease with the increase in the incidence of medication error in nurses requires the attention of managers to plan for measures to improve health and reduce nurses' anxiety, and needs to be considered in critical situations.

Key words: Medication error, General health, Anxiety, Covid-19, Nurse

Funding: This study did not have any funds.

Conflict of interest: None declared.

Ethical approval: The Ethics Committee of Shahrekord Islamic Azad University approved the study (IR.IAU.SHK.REC.1399.062).

How to cite this article: Dastyar A, Karimian Kakolaki Z. Association of Medication Error Occurrence with General Health and Anxiety Caused by Covid-19 Disease in Nurses of Imam Reza Hospital of Ahvaz in 2020: A Descriptive Study. J Rafsanjan Univ Med Sci 2022; 20 (10): 1129-43. [Farsi]

1- MSc Student in Healthcare Services Management, Faculty of Medical Sciences, Shahrekord Branch, Islamic Azad University, Shahrekord, Iran, ORCID: 0000-0003-2091-5630

r- Assistant Prof., PhD in Health Education and Promotion, Dept. of Health, Faculty of Medical Sciences, Shahrekord Branch, Islamic Azad University, Shahrekord, Iran, ORCID: 0000-0002-5946-0955

(Corresponding Author) Tel: (038) 33361047, Fax:(038) 33361031, E-mail: zohrehkarimian68@gmail.com

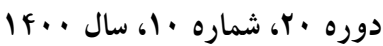

مجله دانشگاه علوم يزشكى رفسنجان 